\title{
Interactions of local climatic, biotic and hydrogeochemical processes facilitate phosphorus dynamics along an Everglades forest-marsh gradient
}

\author{
T. G. Troxler ${ }^{1}$, C. Coronado-Molina ${ }^{2}$, D. N. Rondeau ${ }^{3}$, S. Krupa ${ }^{4}$, S. Newman ${ }^{2}$, M. Manna ${ }^{2}$, R. M. Price ${ }^{1}$, and \\ F. H. Sklar ${ }^{2}$ \\ ${ }^{1}$ Southeast Environmental Research Center, Florida International University, Miami, Florida 33199, USA \\ ${ }^{2}$ Everglades Systems Assessment Section, South Florida Water Management District, West Palm Beach, Florida, USA \\ ${ }^{3}$ Hydrology Department, Everglades National Park, National Park Service, Homestead, Florida, USA \\ ${ }^{4}$ Hydrogeology Unit, South Florida Water Management District, West Palm Beach, Florida, USA
}

Correspondence to: T. G. Troxler (troxlert@fiu.edu)

Received: 20 April 2013 - Published in Biogeosciences Discuss.: 26 June 2013

Revised: 3 December 2013 - Accepted: 17 December 2013 - Published: 18 February 2014

\begin{abstract}
Ecosystem nutrient cycling is often complex because nutrient dynamics within and between systems are mediated by the interaction of biological and geochemical conditions operating at different temporal and spatial scales. Vegetated patches in semiarid and wetland landscapes have been shown to exemplify some of these patterns and processes. We investigated biological and geochemical factors suggested to contribute to phosphorus (P) movement and availability along a forest-marsh gradient in an Everglades tree island. Our study illustrated processes that are consistent with the chemohydrodynamic nutrient (CHNT) hypothesis and the trigger-transfer, pulse-reserve (TTPR) model developed for semiarid systems. Comparison with the TTPR model was constructive as it elaborated several significant patterns and processes of the tree island ecosystem including: (1) concentration of the limiting resource $(\mathrm{P})$ in the source patch (High Head which constitutes the reserve) compared with the resource-poor landscape, (2) soil zone calcite precipitation requiring strong seasonality for evapotranspiration to promote conditions for secondary soil development and calcium phosphate reprecipitation, (3) rewetting of previously dry soils by early wet season precipitation events, and (4) antecedent conditions of the source patch, including landscape position that modulated the effect of the precipitation trigger. Thus, our study showed how water availability drives soil water $\mathrm{P}$ dynamics and, potentially, stability of mineral soil $\mathrm{P}$ in this tree island ecosystem. In landscapes
\end{abstract}

with extensive water management, these processes can be asynchronous with the seasonality of hydrologic dynamics, tipping the balance between a sink and source of a limiting nutrient.

\section{Introduction}

The mobility and transfer of limiting resources is a fundamental premise governing ecosystem structure and processes (McClain et al., 2003). In the Florida Everglades, tree islands are exemplary; many tree islands have upland, forested (e.g., High Head or Dry Head) plant communities with high concentrations of phosphorus $(\mathrm{P})$ on mineral soils in an otherwise highly oligotrophic, P-limited marsh landscape (Noe et al., 2001; McCormick et al., 2009; Ross and Sah, 2011; Wetzel et al., 2011). Tree islands in areas of the remnant deep-water slough often have an elongated "tear-drop" shape that are parallel to the historic flow direction (Wetzel et al., 2005; Ross et al., 2006). This type of tree island is also comprised of forested and herbaceous wetland plant communities downstream of the upland community. Here, aboveground biomass and soil $\mathrm{P}$ concentrations are further stratified along a distinct forest-marsh gradient (see reviews by Wetzel et al., 2005, 2011). Observations of this well-delineated patterning suggest that the distribution of $\mathrm{P}$ is fundamental to the ecosystem structure and functioning of this type of tree 
island. However, drainage and excessive flooding have reduced the area and extent of tree islands. This has resulted not only in the loss of forest structure but also the potential loss of soil P retained in these tree islands (Patterson and Finck, 1999). The effects of $P$ enrichment in Everglades marshes are well-known but generally constrained to point-sources of agricultural run-off (Davis and Ogden, 1994). Loss of tree island soil structure threatens to exacerbate water quality issues related to $\mathrm{P}$ enrichment through localized run-off. Reduced landscape habitat quality for Everglades fauna is also of great concern (Gawlik and Rocque, 1998). Thus, internal $\mathrm{P}$ dynamics and relationships with regional hydrologic pattern are fundamental to understanding: (1) processes that have preserved tree island soil P for millennia and (2) the potential for restoring them where they have been lost.

Observations of tree island vegetation structure and landscape patterning have led to numerous hypotheses about the origin and development of tree islands (Sklar and van der Valk, 2002; Wetzel et al., 2005, 2011; Ross et al., 2006) with paleoecological studies providing the best characterization of tree island and landscape evolution (e.g., Willard et al., 2006; Bernhardt 2011). These observations have also led to studies that model Everglades landscape vegetation dynamics (Ross et al., 2006; Givnish et al., 2008) and several field studies characterizing key aspects of tree island structure, hydrodynamics and plant-water relations (Troxler et al., 2005; Troxler and Childers, 2009; Hanan et al., 2010; Hanan and Ross, 2010; Saha et al., 2009, 2010; Wang et al., 2011; Sullivan et al., 2011, 2012; Espinar et al., 2012). These and other studies have illustrated that local climate conditions, hydrology and nutrient availability are important factors describing the development and structure of tree islands. However, plant-soilwater interactions along the tree island forest-marsh gradient have not been comprehensively addressed. The chemohydrodynamic nutrient (CHNT) hypothesis poses the framework for these interactions (Sklar and van der Valk, 2002). This conceptual model poses that nutrients leach from the P-rich soils of the High Head, contributing to forest productivity and peat accumulation downstream and are aligned with the lateral flow direction of the slough. The model thereby links the limiting nutrient with spatial pattern through internal hydrologic transport. Further model development suggests that differential transpiration would preferentially increase the concentration of ions in soil water in the driest forest community of the island (Focused Nutrient Redistribution; Ross et al., 2006; Wetzel et al., 2006). The CHNT hypothesis invokes the well-known, general ecohydrological framework of the trigger-transfer, pulse-reserve (TTPR) model developed for semiarid and arid systems. The TTPR model conceptualizes a trigger (precipitation event) that results in a transfer of materials that can be recycled into a reserve, utilized for plant growth or lost from the system (Ludwig et al., 2005). Despite the fundamental properties that differentiate systems of semiarid drylands and subtropical wetlands, antecedent conditions (i.e., landscape position, topography, and soil type) and pronounced seasonality of limiting resources (precipitation and P, respectively) conceptualized by the TTPR model may apply in the case of internal $\mathrm{P}$ dynamics along a forestmarsh gradient of an Everglades tree island. However, the CHNT model has not been tested comprehensively with field data nor has it been considered in the context of other ecohydrological models.

In this study, we sought to draw upon the TTPR ecohydrological model for semiarid systems to guide our study of the CHNT hypothesis described for "tear-drop"-shaped Everglades tree islands. Our study was designed to test this hypothesis with field data, identify modes of $\mathrm{P}$ transport and quantify temporal patterns of vertical and lateral mass $P$ flux. We tested the validity of the CHNT by investigating plant-soil-water interactions that linked the limiting nutrient with spatial pattern through hydrologic transport. We postulated that: (1) higher evapotranspiration and upland hydrologic conditions were correlated with high soil $\mathrm{P}$ and hydrogeochemical conditions favoring P retention and (2) water movement, mediated by dry season evapotranspiration, the onset of wet season precipitation, and regional hydrology promoted $\mathrm{P}$ fluxes in the upland forest community and downstream along the gradient. Our objectives were to characterize: (1) tree island soil structure, total $\mathrm{P}$ and $\mathrm{P}$ fractions, (2) spatial and temporal variability in diurnal hydraulic patterns, (3) temporal local and regional hydraulic patterns, and (4) spatial and temporal hydrogeochemical patterns in ions and nutrients along a forest-marsh gradient comprised of four tree island plant communities and the adjacent marsh. We conceptualized this site of high soil $\mathrm{P}$ in the tree island as a $P$ reserve with the release of the limiting nutrient mediated by pulse dynamics and hydrologic transport as has been described by the TTPR for semiarid systems.

\section{Methods}

\subsection{Study site}

Our study was conducted at one tree island site in southern Water Conservation Area 3A (WCA 3A) in the Florida Everglades, located at $25^{\circ} 51^{\prime} \mathrm{N}$ and $80^{\circ} 46^{\prime} \mathrm{W}$. Central WCA $3 \mathrm{~A}$ generally resembles the historic ridge and slough geomorphology (e.g., Science Coordination Team, 2003; Givnish et al., 2008). Tree island cover in central WCA $3 \mathrm{~A}$ has been reduced in aerial extent by approximately $60 \%$ since the 1950 s (Patterson and Finck, 1999). The tree island of study - 3AS3 - is a fixed tree island with a discernible upland, forested High Head plant community that constitutes the dry forest community of the forest-marsh gradient. Downstream of the High Head, in a lateral orientation, is a wetland, forested Wet Head plant community. Downstream of the Wet Head is a Near Tail community that is intermixed with shrubs and trees with open herbaceous vegetation in areas and a sawgrass Far Tail community that is comprised of relatively dense saw 
grass (Cladium jamaicense) intermixed with shrub and other herbaceous vegetation (Fig. 1). Hydrostratigraphic characterization of the tree island provides evidence that the High Head coincides with a discernible topographic high that originated with the underlying Pliocene Tamiami sand formation and Pleistocene age marine limestone (McNeill and Cunningham, 2003).

Our study focused on comparisons among the described four plant communities within an Everglades tree island and the adjacent marsh community. The species composition of the High Head and Wet Head communities were similar, with Chrysobalanus icaco dominating and only a few individuals of Salix caroliniana, Ilex cassine, and Annona glabra. The Near Tail community had greater species richness and was dominated by an assemblage of mesophytic and hydrophytic tree species (S. caroliniana, Magnolia virginiana, A. glabra, C. icaco, Myrica cerifera, Persea palustris, and I. cassine). The Far Tail community was characterized by a dense, mixed shrub and herbaceous plant cover with Cephalanthus occidentalis, Cladium jamaicense and S. caroliniana. The marsh community was an open water aquatic system (slough) with Nymphaea odorata and Eleocharis cellulosa typically dominating the vegetation structure within central WCA 3A.

\subsection{Soil characterization}

Twenty-one cores were collected from the four tree island communities and adjacent marsh in 2003 (High Head: $n=3$, Wet Head: $n=5$, Near Tail: $n=8$, Far Tail: $n=3$, Marsh: $n=2$; Table 1 in the Supplement). The top $30 \mathrm{~cm}$ of each core was sectioned into $10 \mathrm{~cm}$ increments and bulk roots removed. The subsections were dried at $70^{\circ} \mathrm{C}$, and processed for ash content, bulk density, soil moisture content, total carbon (TC), total nitrogen (TN), and total phosphorus (TP) analyses. TP was determined from acid-digested samples (Method 365.4 and 365.2 of the US EPA 1983). TN and TC were determined from finely ground soil samples using a Carlo-Erba NA 1500 C-H-N-S analyzer (Hank-Buchler Instruments, Saddlebrook, NJ). Soil fractionation followed an inorganic $\mathrm{P}$ fractionation scheme using a modified Hieltjes and Lijklema (1980) method as described in Reddy et al. (1998). Briefly, instead of $1 \mathrm{M} \mathrm{NH}_{4} \mathrm{Cl}, 1 \mathrm{M} \mathrm{KCl}$ was used and the $0.1 \mathrm{M} \mathrm{NaOH}$ extract was analyzed for TP, with the difference between TP and inorganic $\mathrm{P}(\mathrm{Pi})$ assumed to be organic $\mathrm{P}$ associated with humic and fulvic acids (Reddy et al., 1998). Like $\mathrm{NH}_{4} \mathrm{Cl}, \mathrm{KCl}$ is a neutral salt and commonly used to measure exchangeable $\mathrm{NH}_{4}-\mathrm{N}$. As a result, some researchers have replaced $\mathrm{NH}_{4} \mathrm{Cl}$ with $\mathrm{KCl}$ in this extraction scheme, thus allowing measurement of exchangeable $\mathrm{N}$ and $\mathrm{P}$ simultaneously, though only $\mathrm{P}$ was measured here. Soil $\mathrm{P}$ was fractionated into five compounds: labile $\mathrm{P}$ (KCl-Pi), $\mathrm{Fe} / \mathrm{Al}$-bound $\mathrm{P}(\mathrm{NaOH}-\mathrm{Pi})$, organic $\mathrm{P}(\mathrm{NaOH}-\mathrm{Po}=\mathrm{NaOH}-$ $\mathrm{TP}-\mathrm{NaOH}-\mathrm{Pi}), \mathrm{Ca} / \mathrm{Mg}$ bound $\mathrm{P}(\mathrm{HCl}-\mathrm{Pi}, 0.5 \mathrm{M} \mathrm{HCl})$, and calculated residual P. The TP concentration in the $\mathrm{NaOH}$ ex- tract solutions was assessed via standard Pi methods following acid digestion.

\subsection{Meteorological data and hydraulic characterization}

Precipitation and potential evapotranspiration data were obtained from a weather station operated by the South Florida Water Management District (SFWMD) located at the High Head of the tree island. Evapotranspiration was calculated from meteorological data using the "simple method" (SFWMD, 2008). We determined daily climatological precipitation deficit (Prec-ET) from the difference in daily precipitation and evapotranspiration and calculated the cumulative Prec-ET for each of the six bimonthly periods from February 2008-February 2009. We estimated the precipitation sum for these same periods.

To characterize hydraulic patterns in shallow subsurface waters, we installed wells in two parallel transects across Wet Head and Near Tail communities. We established a third transect in the High Head that was perpendicular to the Wet Head and Near Tail transects (Fig. 1). Five clusters across each parallel transect, with two wells per cluster, were installed to $0.3 \mathrm{~m}$ and $0.6 \mathrm{~m}$ below the soil surface. Two additional well clusters completed the third transect located in the High Head. The well design was a 2" PVC slotted along a $10 \mathrm{~cm}$ length at the bottom of the pipe and fit with pressure transducer $\left(\mathrm{In}-\mathrm{situ}^{\circledR}\right)$ water level gauges. We installed each well by excavating an approximately $20 \mathrm{~cm}$ diameter hole with a gas-powered hand auger. To ensure that the wells did not migrate due to peat shrinkage or swelling, the pipes were installed with anchor and well sections. The borehole for each well was excavated to limestone where the anchor section rested. The well screen was $0.2-0.3 \mathrm{~m}$ and $0.5-0.6 \mathrm{~m}$ below the soil surface for shallow and deep wells, respectively, and capped at the end. The annular area surrounding the anchor section was filled with fine sand. The annular area surrounding the well screen was then filled with 6/20 filter sand. Each well was capped with bentonite (Enviroplug No. 8, WYOBEN).

Hydraulic patterns of regional groundwater were characterized using head levels from groundwater wells installed by the SFWMD (Fig. 1). These wells were approximately $2 \mathrm{~m}$ and $8 \mathrm{~m}$ below the peat surface (average peat depth $\sim 1 \mathrm{~m}$ ), installed into limestone bedrock and sand, respectively (Bevier and Krupa, 2001; McNeil and Cunningham, 2003). A final set of shallow wells was installed by the SFWMD at $0.1-0.3 \mathrm{~m}$ and $0.4-0.5 \mathrm{~m}$ depths in clusters located in the Far Tail and Marsh.

All wells were surveyed relative to the nearest benchmark using a Leica ${ }^{\mathrm{TM}} \mathrm{TC} 805$ electronic total station determined by differential leveling from stainless steel rod monuments located on or adjacent to the island (Florida Department of Environmental Protection bench mark 3AS3-GW1-4, National Geodetic Vertical Datum 29). Water depth (mm) was 


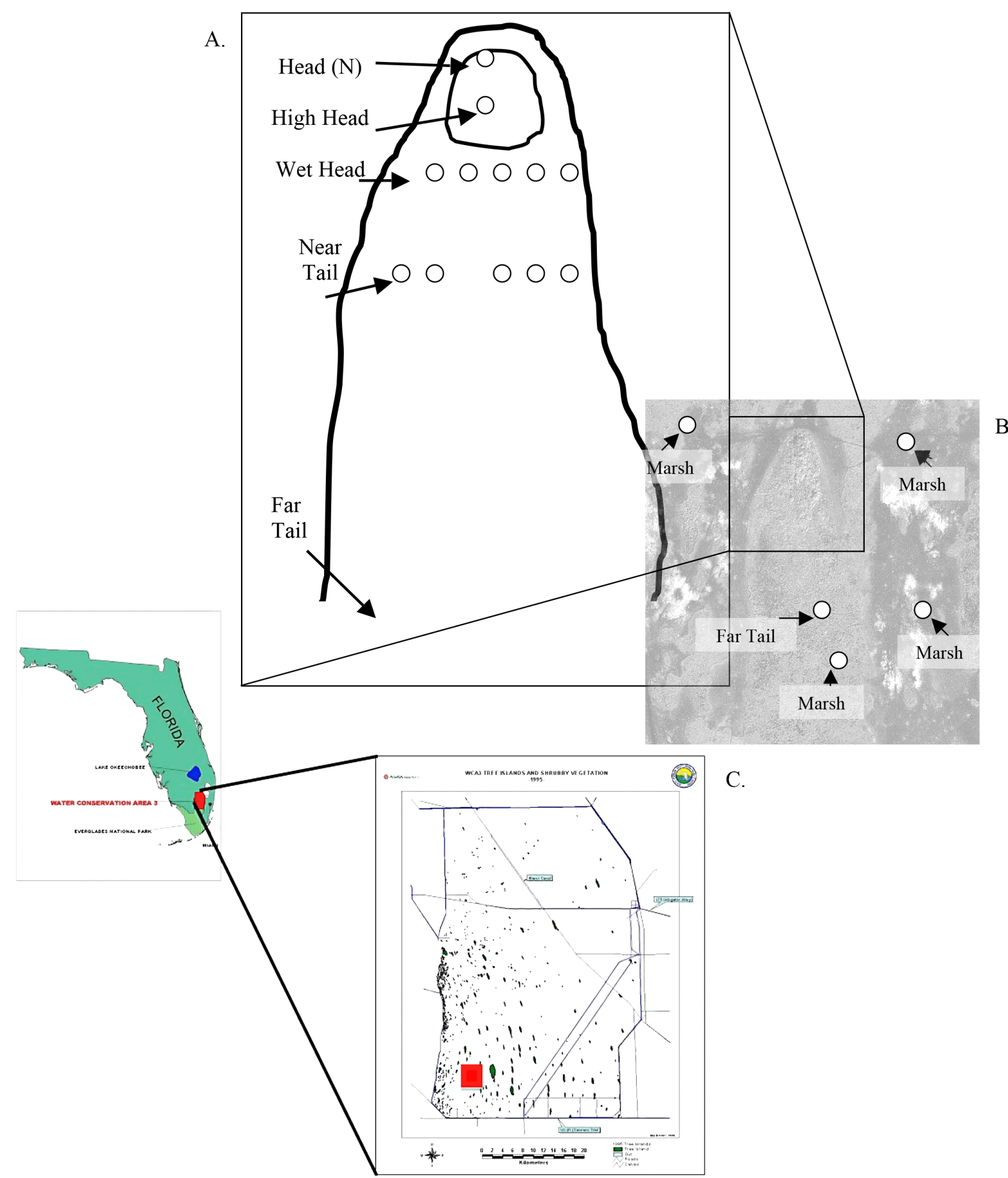

Fig. 1. Map of tree island piezometer (A) and well locations (B). Piezometers were installed to a depth of 0.3 and $0.6 \mathrm{~m}$. Wells were installed to a depth of 2 and $8 \mathrm{~m}$. At the Far Tail location there were both piezometers and wells as described. Also illustrated is the tree island 3AS3 study site (red box) in the WCA 3A (C) in Florida.

recorded at $15 \mathrm{~min}$ intervals in each well to obtain hydraulic head levels. Data from the groundwater wells were obtained from DBHYDRO (www.sfwmd.gov). Estimates of hydraulic conductivity at 0.3 and $0.6 \mathrm{~m}$ depths were obtained using slug 
tests following the Hvorslev method (Schwartz and Zhang, 2003).

\subsection{Hydrochemical sampling}

We conducted four samplings of shallow soil water and groundwater in the four tree island communities and adjacent marsh in August 2007, February and August 2008 and February 2009. August is typically considered early wet season while February is early dry season, but hydrologic conditions during these months can vary interannually depending on regional precipitation and water management. When present, we also collected surface water samples from Marsh and Far Tail tree island locations.

Wells were purged of three well volumes and dissolved oxygen (Clark cell), temperature (thermistor in stainless steel tube), $\mathrm{pH}$ (glass sensor with reference electrode) and specific conductivity (four electrode cell methodology) were measured with a Hydrolab Quanta multiparameter sonde (Hach, Loveland, CO, USA) and recorded after three stable readings using a flow-through vessel. Wells were then purged a fourth time for sample collection and water filtered through $0.45 \mu \mathrm{m}$ glass fiber filters. Surface waters were similarly sampled. Samples were analyzed for total dissolved nitrogen (TDN) and total dissolved phosphorus (TDP), soluble reactive $P$ (SRP), nitrate + nitrite $\left(\mathrm{NO}_{2}+\mathrm{NO}_{3}\right)$, and ammonium $\left(\mathrm{NH}_{4}\right)$ at the Florida International University SERC Laboratory. Filtered water samples were analyzed for SRP, $\mathrm{NH}_{4}$, $\mathrm{NO}_{3}+\mathrm{NO}_{2}$, and $\mathrm{NO}_{2}$ concentrations using a four-channel auto-analyzer (Alpkem model RFA 300), and for TDN using an Antec $7000 \mathrm{~N}$ Total Nitrogen analyzer (Frankovich and Jones, 1998). TDP was analyzed with a modified Solorzano and Sharp (1980) method. Analyses of $\mathrm{Ca}, \mathrm{Cl}, \mathrm{Mg}, \mathrm{K}$, $\mathrm{Na}, \mathrm{SO}_{4}$, alkalinity as $\mathrm{CaCO}_{3}$, and total dissolved solids (TDS) were conducted by the SFWMD analytical lab following Environmental Protection Agency protocols. Mineral saturation indices (SI) of calcite and aragonite were determined using Aq-QA ${ }^{\circledR}$ (Rockware Inc.) where $\mathrm{SI}=\log Q / K$ and $Q=$ ion activity product and $K=$ equilibrium constant. For calcite and aragonite, $Q$ was defined by the activity coefficients and molar concentrations of $\mathrm{CO}_{3}^{-2}$ and $\mathrm{Ca}^{+2}$. Hydroxyapatite saturation indices were determined using PHREEQC ${ }^{\odot}$ (Parkhurst and Appelo, 1999). For the saturation index of hydroxyapatite, $Q$ was defined by the activity coefficients and molar concentrations of $\mathrm{HPO}_{4}^{-2}$ and $\mathrm{Ca}^{+2}$. Two equivalent modeling programs were used to cross-check results and calculate an additional saturation index relative to hydroxyapatite.

We quantified the average lateral hydraulic gradient as the difference in hydraulic head levels between a well in the High Head and three wells in the Wet Head. We calculated the lateral hydrologic flux using the average hydraulic head gradient and hydraulic conductivity to compute the specific discharge $\left(q ; \mathrm{mm} \mathrm{h}^{-1}\right)$. We calculated lateral porewater flux $\left(\mu \mathrm{g} \mathrm{m}^{-2} \mathrm{~d}^{-1}\right.$; advective mass flux) using High Head TDP concentrations at $60 \mathrm{~cm}$ depth (assuming uniform concentrations for these soils at this depth and that advective mass flux was the main transport mechanism from the High Head to Wet Head) and effective porosity of 0.75 . We determined the vertical porewater recharge and $\mathrm{P}$ flux associated with recharge of soil water applying the recovery rate of porewater (Mrc) upon diurnal drawdown for the High Head and Wet Head communities. We calculated the Mrc as the difference in minimum and maximum water levels between 14:00 to $04: 00 \mathrm{~h}$ for each $24 \mathrm{~h}$ period (Gerla, 1992) multiplied by effective porosity. Soil porewater recharge rate was calculated for periods with and without precipitation to partition recharge associated with precipitation and diurnal drawdown as compared with diurnal drawdown only.

\subsection{Statistical analyses}

We scaled the variability in diurnal and daily hydraulic patterns to report intra-annual variation in hydrologic conditions and estimated flux rates associated with porewater recharge, lateral specific discharge and $\mathrm{P}$ transport. Bimonthly periods were characterized as early dry (February-March 2008), dry (April and June 2008; too dry in May), early wet (JulyAugust 2008), wet (September-October 2008), late wet (November-December 2008), and late late wet (JanuaryFebruary 2009). We then related variation in regional climate (bimonthly, cumulative sum of Prec-ET and precipitation) with daily water level and flux rates for the High Head and Wet Head using regression analysis.

We tested the mean difference in soil parameters including soil $\mathrm{P}$ fractions, nutrient, TC, ash content and bulk density using one- and two-way ANOVA and Student's $t$ multiple comparisons test. We tested the mean difference in TDP, $\mathrm{SI}_{\text {calcite }}$ and $\mathrm{SI}_{\text {aragonite, }}$, ratio of $\mathrm{Ca}$ to $\mathrm{Cl}$ and $\mathrm{pH}$ using mixed effects models with sampling period as the random effect in three tests: (1) the effect of community type, (2) the interaction effect of community type and soil water depth and (3) the main effects of community type and water type (shallow soil water and groundwater). We used Tukey HSD and Student's $t$ multiple comparisons tests. We also tested the influence of regional climate variables of precipitation, evapotranspiration, and tree island water level on fluxes of water and $\mathrm{P}$ using regression analyses. All parameters had approximately normal distributions and equal variances except TDP concentrations that were transformed using a cube root transformation. Statistical analyses were conducted using JMP 8.0 (SAS Institute).

\section{Results}

\subsection{Soil characterization}

Soil $\mathrm{P}$ concentrations $\left(\mathrm{mg} \mathrm{kg}^{-1}\right)$ were on average 38 times higher in High Head soils than the average of peat soils in Wet Head, Near Tail, Far Tail and Marsh communities 

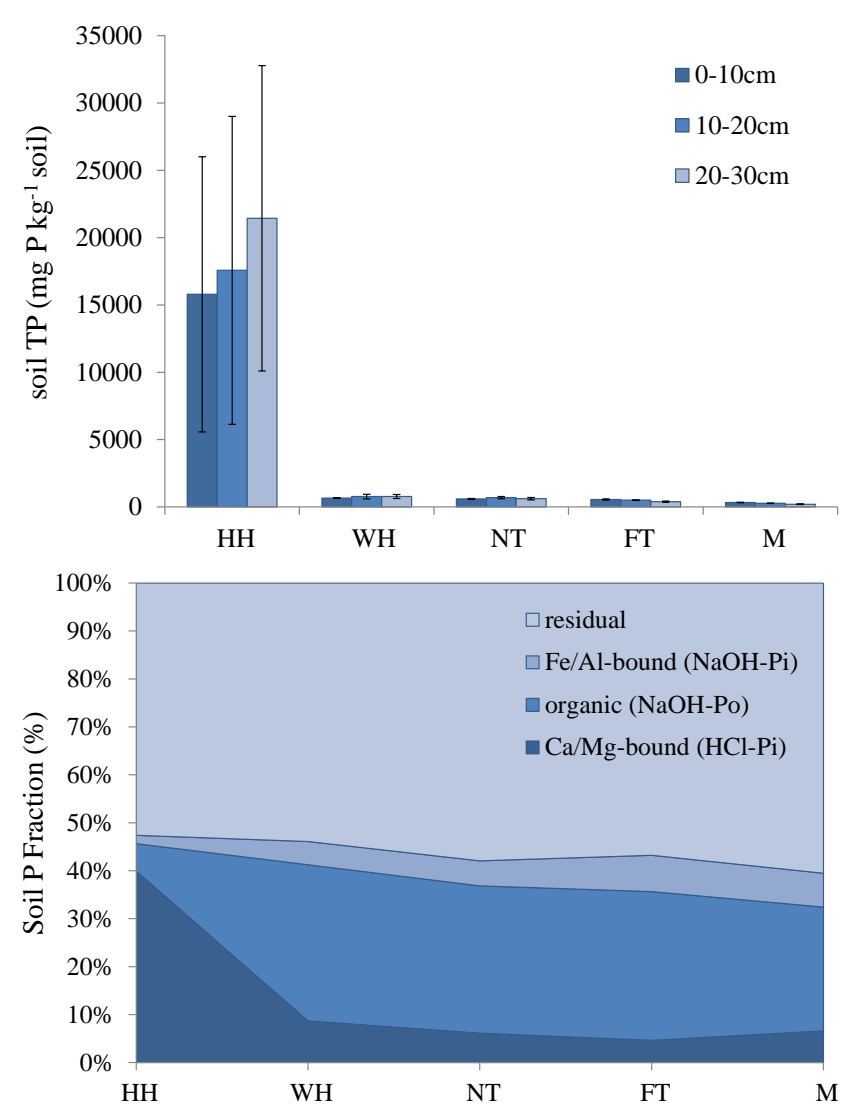

Fig. 2. (a) Soil total phosphorus concentrations in five plant communities High Head (HH), Wet Head (WH), Near Tail (NT), Far Tail (FT), and Marsh (M) and at three depths in tree island 3AS3. Error bars represent standard error. (b) Fractions of soil phosphorus in the $0-10 \mathrm{~cm}$ depth profile for five plant communities in tree island $3 \mathrm{AS} 3$.

(Fig. 2a; $F=3.86, p=0.0002$ ) despite high variability among sampling locations in High Head soils. Total P concentrations for peat soils averaged less than $500 \mu \mathrm{g} \mathrm{P} \mathrm{g}^{-1}$ soil and differed little with depth. There was also strong differentiation between soil $\mathrm{P}$ fractionations of the High Head and other plant communities (Fig. 2b). The High Head soils had the highest average proportion of $\mathrm{Ca} / \mathrm{Mg}$-bound $\mathrm{P}(\mathrm{HCl}-\mathrm{Pi}$; $F=10.06, p<0.0003)$. In other soils, this proportion averaged 3-7 \% Ca/ Mg-bound soil $\mathrm{P}$, was inversely proportional to organic $\mathrm{P}$, and thus significantly lower in High Head soils as compared to other communities (NaOH-Po; $F=12.76$, $p<0.0001$ ). There was little labile $\mathrm{P}$ (as defined by KCl-Pi; not shown) in tree island soils and $\mathrm{Fe} / \mathrm{Al}$-bound $\mathrm{P}$ was similar to the proportion of $\mathrm{Ca} / \mathrm{Mg}$-bound $\mathrm{P}$ in communities with peat soils. In general, soils of Wet Head, Near Tail, Far Tail and Marsh had similar P fractions.

There were also notable differences in $\mathrm{TN}, \mathrm{TC}, \mathrm{Ca}$, ash content, bulk density, and TP expressed in g/volume and the mass ratio of $\mathrm{Ca}: \mathrm{Ca} / \mathrm{Mg}$-bound $\mathrm{P}$ (HCl-Pi) (Supplement). All parameters varied significantly across commu-

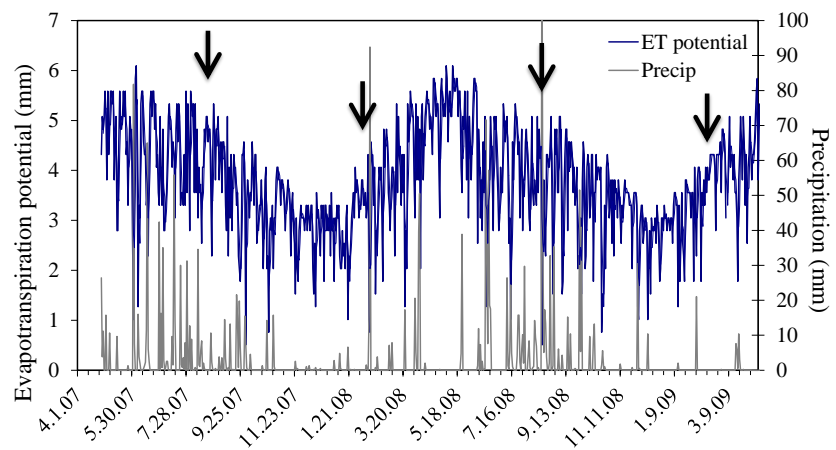

Fig. 3. Potential evapotranspiration (ET) and precipitation in tree island 3AS3. Recorded from High Head (HH) location.

nity types with High Head soils having lower TN, TC and $\mathrm{Ca}: \mathrm{Ca} / \mathrm{Mg}$-bound $\mathrm{P}$ and higher $\mathrm{Ca}$, ash content, bulk density, and TP ( $\mu \mathrm{g} \mathrm{cm}^{-3}$; Supplement). Only bulk density and ash content significantly varied with soil depth $(p=0.019$ and $p=0.048$, respectively; $20-30 \mathrm{~cm}$ depth higher than 0 $10 \mathrm{~cm}$ depth). There was a trend of decreasing TC content with depth, but this was not significant at $\alpha=0.05$ ( $p=$ $0.063)$.

\subsection{Meteorological data and hydraulic patterns}

Evapotranspiration was evidently seasonal and highest in the late dry season months (i.e., May; Fig. 3). Cumulative rainfall measured at the SFWMD 3AS3 weather station was $97.8 \mathrm{~cm}$ in 2007 and $124.6 \mathrm{~cm}$ in 2008. In 2007, the early dry season was exceptionally dry (March 2007; data not shown) and recovered only approximately $65 \%$ of annual average rainfall by the end of the year. This contributed to relatively low water levels in the 2007-2008 wet season (August-January) and among the lowest water levels in the dry season of 2008 (February-June; Table 1). High precipitation in the 2008 wet season contributed to more typical wet and dry season patterns (August 2008-May 2009; Fig. 3, Table 1). The sampling periods characterized regional conditions as follows: (a) August $2007 \sim$ warm, dry; (b) February 2008 cool, dry; (c) August 2008 warm, wet; (d) February $2009 \sim$ cool, wet.

We characterized variability in seasonal and diurnal patterns of shallow hydraulic head levels by contrasting six-day intervals among early dry (21-27 April), early wet (11-17 September) and late wet (8-13 December) seasons. In the early dry season, the water table was receding and diurnal changes in water levels were observed in both plant communities (Fig. 4a). However, we found that diurnal fluctuations of the water table in the High Head were greater than in the Wet Head. Water table drawdown in the High Head was 8$10 \mathrm{~mm}$ lower mid-day when compared with overnight levels. The average daily evapotranspiration measured at this early dry season period was $5.3 \pm 0.5 \mathrm{~mm}$. In the early wet season, the diurnal drawdown in the water level was also observed 

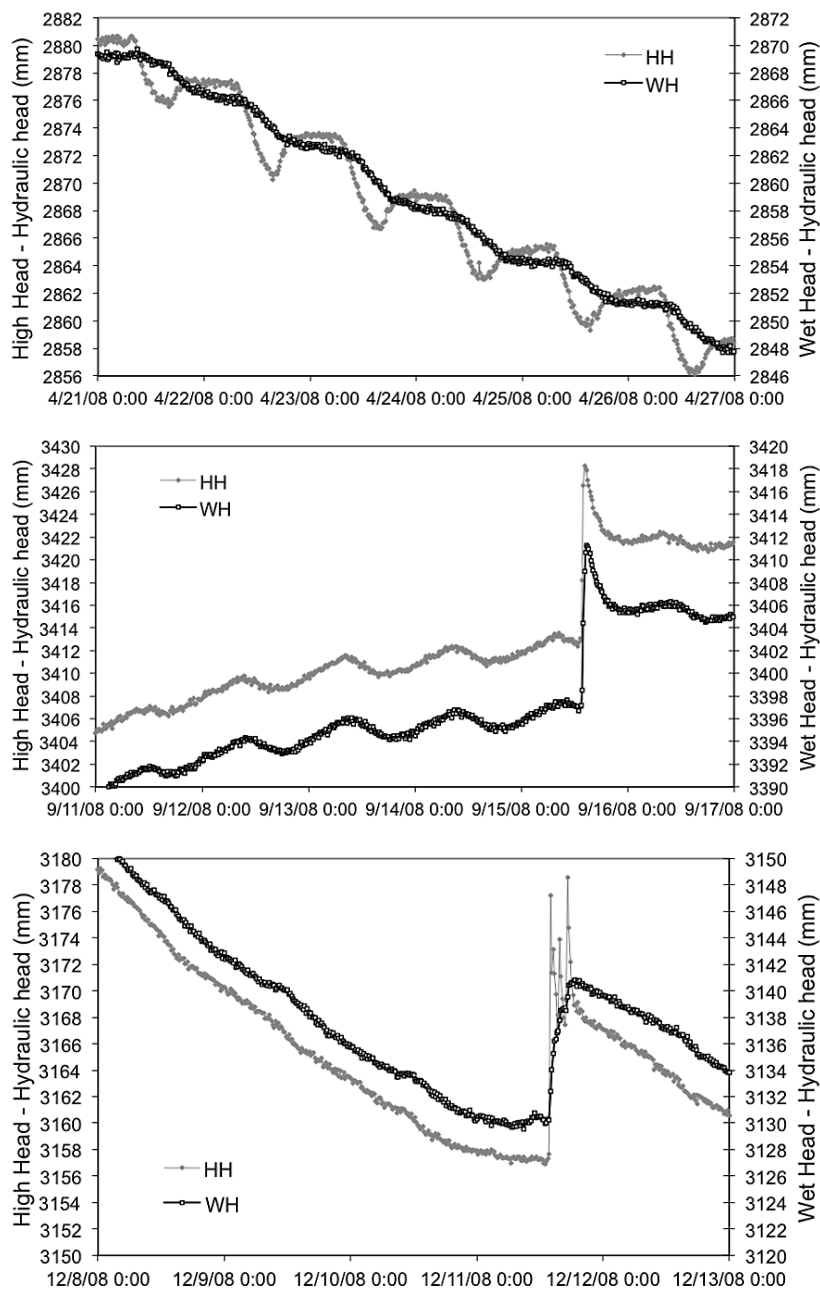

Fig. 4. (a) Early dry season (21-27 April 2008) hydraulic head levels at $15 \mathrm{~min}$ intervals in central High Head (HH) and Wet Head (WH) locations at $60 \mathrm{~cm}$ depth. (b) Early wet season (11-17 September 2008) hydraulic head levels at 15 min intervals in central High Head $(\mathrm{HH})$ and Wet Head (WH) locations at $60 \mathrm{~cm}$ depth. (c) Late wet season (8-13 December 2008) hydraulic head levels at 15 min intervals in central High head $(\mathrm{HH})$ and Wet Head $(\mathrm{WH})$ locations at $60 \mathrm{~cm}$ depth.

but similar for both communities (Fig. 4b). The water table at this time was increasing and measured evapotranspiration was $4.3 \pm 0.8 \mathrm{~mm}$. Even as a precipitation event occurred on 16 September, and the hydraulic head level increased, the diurnal signal continued uninterrupted into the following days. In the late wet season, the diurnal water level drawdown was completely absent for both plant communities (Fig. 4c). Water levels were again receding and evapotranspiration was approximately half that of the early dry and early wet season samplings averaging $2.5 \pm 0.8 \mathrm{~mm}$.

Between February and July 2008, shallow tree island (0.6 $\mathrm{m}$ depth) and regional groundwater $(2 \mathrm{~m}$ and $8 \mathrm{~m}$ depth) levels generally declined; there was a $>15.2 \mathrm{~cm}$ decline in water levels at $2 \mathrm{~m}$ and $8 \mathrm{~m}$ from 7 April-15 June 2008 (data not shown). In response to local precipitation events, water levels of shallow tree island soils and regional groundwater increased sharply, especially in the dry season. For example, during a dry season precipitation event, the increase in tree island soil water table exceeded $7.6 \mathrm{~cm} \mathrm{~d}^{-1}$ with an equivalent increase in the regional groundwater level within two days. In December 2008, low precipitation led to a rapid decline in regional groundwater levels from a peak at $3.53 \mathrm{~m}$ to a low of $3.17 \mathrm{~m}$.

We also determined hydrologic variability by contrasting conditions of cumulative Prec-ET, precipitation sum, and daily average water level relative to the soil surface as well as porewater recharge rate and lateral specific discharge (Table 1, Fig. 5). Cumulative Prec-ET illustrated a precipitation deficit in all bimonthly periods except the early wet season (July-August 2008), when bimonthly precipitation was greatest. Average water levels in the High Head were always below the soil surface except in the wet and late wet seasonal periods. In the Wet Head, average water levels were always above the soil surface and exceeded $0.5 \mathrm{~m}$ between September and December 2008. The Near Tail community water levels were lower than the Wet Head water levels but showed higher spatial variability. Porewater recharge rate was highest during the dry and early wet season periods for the High Head and Wet Head but the rates were nearly three times higher in the High Head as compared with the Wet Head (Table 1, Fig. 5). Between early dry season and early wet season, lateral specific discharge rates in the High Head were 1-2 orders of magnitude lower than porewater recharge rates. In the wet season (September-October 2008) through the late wet season, the lateral specific discharge rates nearly doubled and were more similar to the porewater recharge rates in both High Head and Wet Head communities. Additionally, a key parameter in the lateral discharge pattern was the lateral hydraulic head gradient (Fig. 5). Moreover, there was an initial increase in porewater recharge in the dry and early wet seasons followed by an increase in lateral head gradient and specific discharge in the wet and late wet seasonal periods.

\subsection{Surface and groundwater hydrochemical patterns}

Water quality data were summarized to present values for $\mathrm{SI}_{\text {calcite }}, \mathrm{SI}_{\text {aragonite }}$ and $\mathrm{SI}_{\text {hydroxyapatite }}, \mathrm{Ca} / \mathrm{Cl}, \mathrm{pH}$ and TDP (Table 2a). We evaluated the mean difference in community values for each of these parameters. The effect of depth could not be evaluated across all community types because of water levels below $30 \mathrm{~cm}$ depth in the High Head during three out of four sampling events (i.e., data were unavailable) and thus both soil water depths were combined in the analysis. Thus, to examine variation over soil water depth (between 0.3 and $0.6 \mathrm{~m}$ ), we excluded the High Head from a second analysis.

There was a significant effect of community type on mean values for each parameter sampled. TDP concentrations were significantly higher in High Head and Wet Head 
Table 1. Intra-annual variability in hydrologic variables summed or averaged over a two-month period characterizing different regional and local hydrologic conditions. Parameters include a measure of the climatological precipitation deficit [cumulative (Prec) precipitation minus evapotranspiration (ET)], sum of precipitation (Prec), water level (WL) relative to the soil surface $(n=3)$ of High Head $(\mathrm{HH})$, Wet Head $(\mathrm{WH})$ and Near Tail (NT), net porewater inflow (Mrc) for the High Head (HH) and Wet Head (WH) and specific discharge $(q)$. Standard error values are indicated below mean values. See text for further details of calculations.

\begin{tabular}{lcccccccc}
\hline & $\begin{array}{c}\text { Cumulative } \\
\text { Prec-ET } \\
\mathrm{mm} / 2 \mathrm{mo}\end{array}$ & $\begin{array}{c}\text { Prec } \\
(\mathrm{sum}) \\
\mathrm{mm} / 2 \mathrm{mo}\end{array}$ & $\begin{array}{c}\text { Daily WL relative } \\
\text { to soil surface } \\
\mathrm{mm}\end{array}$ & $\begin{array}{c}\text { Net porewater } \\
\text { recharge (Mrc) } \\
\mathrm{mm} \mathrm{d}^{-1}\end{array}$ & $\begin{array}{c}\text { Lateral specific } \\
\text { discharge }(q) \\
\mathrm{mm} \mathrm{d}^{-1}\end{array}$ \\
\hline Season & & & $\mathrm{HH}$ & $\mathrm{WH}$ & $\mathrm{NT}$ & $\mathrm{HH}$ & $\mathrm{WH}$ & $\mathrm{HH}-\mathrm{WH}$ \\
Early dry & -74.4 & 146.8 & -338 & 115 & 44 & 7.1 & 5.7 & 0.4 \\
(Feb-Mar 2008) & & & \pm 4 & \pm 21 & \pm 44 & \pm 3.6 & \pm 1.7 & \pm 0.2 \\
Dry & -16.0 & 345.4 & -326 & 74 & 3 & 26.1 & 10.3 & 0.5 \\
(Apr and Jun 2008) & & & \pm 2 & \pm 20 & \pm 44 & \pm 12.6 & \pm 3.4 & \pm 0.2 \\
Early wet & 238.3 & 474.5 & -222 & 244 & 156 & 30.3 & 10.1 & 0.7 \\
(July-Aug 2008) & & & \pm 12 & \pm 19 & \pm 35 & \pm 7.7 & \pm 1.7 & \pm 0.0 \\
Wet & -40.1 & 176.0 & 244 & 706 & $646^{*}$ & 8.7 & 9.0 & 1.2 \\
(Sep-Oct 2008) & & & \pm 8 & \pm 16 & \pm 55 & \pm 1.9 & \pm 1.8 & \pm 0.3 \\
Late wet & & & & & & \\
(Nov-Dec 2008) & -136.4 & 44.7 & 22 & 502 & $453^{*}$ & 6.2 & 5.4 & 1.4 \\
Late late wet & & & \pm 14 & \pm 6 & \pm 12 & \pm 0.9 & \pm 0.9 & \pm 0.3 \\
(Jan-Feb 2009) & -177.3 & 23.4 & -246 & 216 & $129^{*}$ & 6.4 & 4.0 & 0.8 \\
\hline
\end{tabular}

* Average of two sites.

soil water as compared with other communities $(F=17.4$, $p<0.0001)$. Tukey's test of multiple comparisons showed that mean $\mathrm{SI}_{\text {calcite }}$ and $\mathrm{SI}_{\text {aragonite }}$ were significantly higher in High Head, High Head (North), and Near Tail soil water as compared with Wet Head, Far Tail and Marsh $(F=$ 29.4, $p<0.0001)$. Wet Head soil water was also significantly higher than Far Tail and Marsh $(F=29.3, p<0.0001)$. Mean $\mathrm{Ca} / \mathrm{Cl}$ was significantly lower in High Head soil water as compared with all communities sampled $(F=8.9, p=$ 0.0002 ). Mean $\mathrm{pH}$ was significantly higher in soil water of High Head and High Head (N) than soil water of all other communities sampled $(F=13.5, p<0.0001)$.

To evaluate the effects of community and depth, only the significance test of the community-depth interaction is presented. There was a significant interaction effect for all parameters except $\mathrm{Ca} / \mathrm{Cl}$ (TDP: $F=7.8, p=0.0019$; $\mathrm{SI}_{\text {calcite }}$ : $F=17.3, p=0.0001 ; \mathrm{SI}_{\text {aragonite }}: F=10.6, p=0.0001$; $\mathrm{pH}: F=10.0, p=0.0005)$ with both main effects also significant (data not shown). Tukey's test of multiple comparisons showed that mean TDP was highest in the Wet Head at $0.3 \mathrm{~m}$ depth, followed by $0.6 \mathrm{~m}$ depth, with all other depths not significantly different (excluding the High Head which was not included in the analysis). For calcite and aragonite saturation indices, values at $0.6 \mathrm{~m}$ depth in Wet Head, Near Tail and High Head (North) and in High Head (North) at $0.3 \mathrm{~m}$ depth were significantly higher than values at $0.3 \mathrm{~m}$ depth for Wet Head, Near Tail, Far Tail and slough and at $0.6 \mathrm{~m}$ depth in the Far Tail and slough. Mean $\mathrm{pH}$ values were highest at $0.6 \mathrm{~m}$ depth in High Head (North). Mean pH values were lower at $0.6 \mathrm{~m}$ depth in Wet Head and Near Tail and at $0.3 \mathrm{~m}$ depth at High Head (North) but significantly higher than values at $0.3 \mathrm{~m}$ in Wet Head, Near Tail, Far Tail and Marsh and at $0.6 \mathrm{~m}$ depth in Marsh. Mean pH at $0.6 \mathrm{~m}$ in Far Tail was not significantly different between these two latter groups.

Statistical comparisons of the means presented in Table $2 \mathrm{a}$ were also categorized by either soil water $(0.2-0.3$ and $0.5-$ $0.6 \mathrm{~m}$ depth) or groundwater ( $2 \mathrm{~m}$ or $8 \mathrm{~m}$ depth) and compared for those communities where these depths were simultaneously sampled (High Head, Far Tail and Marsh; Table $2 b$ ). Surface water samples were excluded from the analysis. There was strong differentiation between soil water and groundwater for nearly all communities sampled. The soil water in the High Head had significantly higher TDP than other samples. The $\mathrm{SI}_{\text {calcite }}$ and $\mathrm{SI}_{\text {aragonite }}$ of High Head soil water was significantly higher than soil water of the Far Tail and Marsh but not significantly different from the groundwater of High Head, Far Tail or Marsh. As a main effect, the High Head had the lowest $\mathrm{Ca} / \mathrm{Cl}$ and groundwater had higher $\mathrm{Ca} / \mathrm{Cl}$ than soil water. An interaction effect showed that soil water $\mathrm{pH}$ was higher in the High Head than in Far Tail or Marsh and was not significantly different from $\mathrm{pH}$ of the High Head groundwater. TDP in the soil water of the Far Tail was significantly higher than the groundwater of the Far Tail and Marsh (Table 2b). 


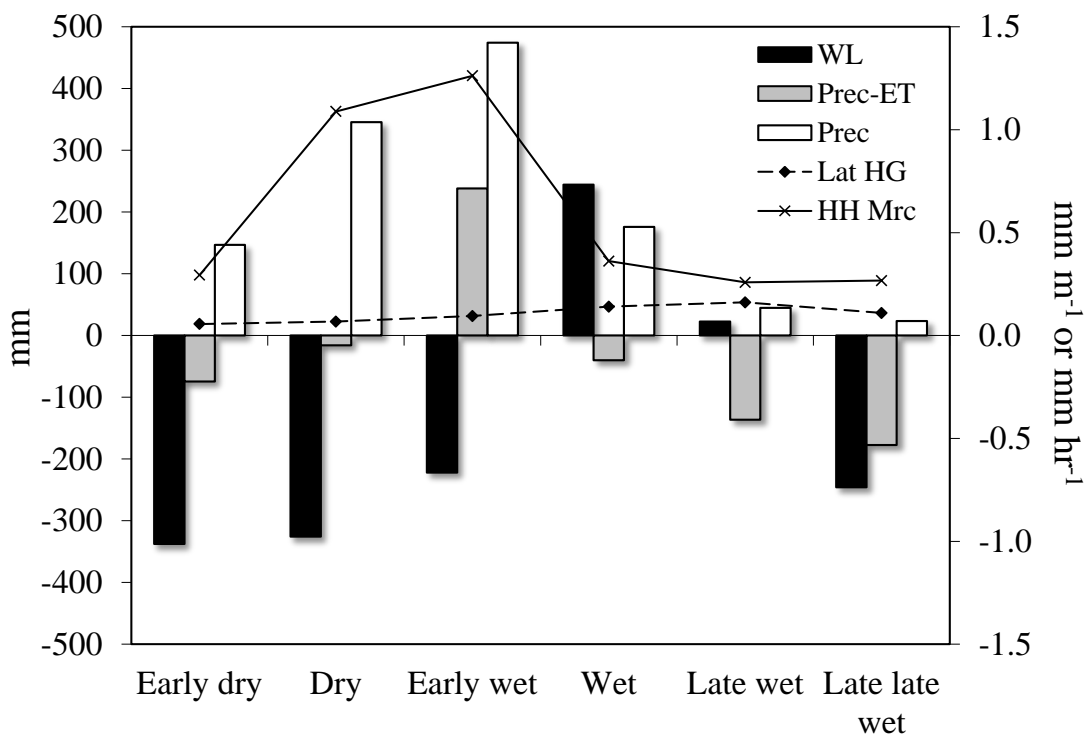

Fig. 5. Seasonal pattern of High Head water level (WL), precipitation deficit (Prec-ET), cumulative precipitation (Prec), lateral hydraulic gradient from High Head to Wet Head (Lat HG), and porewater recovery rate in the High Head (HH Mrc). See Table 1 for estimates of standard error where available.

Table 2a. Calculated indices of mineral saturation, the ratio of $\mathrm{Ca}$ to $\mathrm{Cl}, \mathrm{pH}$ and TDP in four tree island plant communities and adjacent deep-water slough averaged over the four sampling periods with standard error. For mineral saturation, supersaturated (SI $>0 \pm 0.10$ ), approximately saturated (SI $\sim 0 \pm 0.10$ ), and undersaturated $(\mathrm{SI}<0 \pm 0.10$ ) with respect to calcite, aragonite and hydroxyapatite as indicated. Average charge balance errors were $<3 \%$ for most samples (see Supplement).

\begin{tabular}{|c|c|c|c|c|c|c|c|}
\hline \multirow{2}{*}{$\begin{array}{l}\text { Community } \\
\text { type }\end{array}$} & \multirow{2}{*}{$\begin{array}{l}\text { Depth } \\
\text { (m) }\end{array}$} & \multicolumn{3}{|c|}{ Mineral saturation } & \multirow[b]{2}{*}{$\mathrm{Ca} / \mathrm{Cl}$} & \multirow[b]{2}{*}{ pH (units) } & \multirow{2}{*}{$\begin{array}{c}\text { TDP } \\
\left(\mu \mathrm{mol} \mathrm{L}{ }^{-1}\right)\end{array}$} \\
\hline & & $\mathrm{SI}_{\text {calcite }}$ & $\mathrm{SI}_{\text {aragonite }}$ & SI $_{\text {hydroxy }}$ & & & \\
\hline \multirow[t]{2}{*}{ HEAD (N) } & $0.2-0.3$ & $0.107 \pm 0.06$ & $-0.058 \pm 0.06$ & -4.29 & $4.49 \pm 0.28$ & $6.75 \pm 0.03$ & $0.61 \pm 0.33$ \\
\hline & $0.5-0.6$ & $0.398 \pm 0.04$ & $0.233 \pm 0.04$ & -2.75 & $5.09 \pm 0.17$ & $7.08 \pm 0.05$ & $0.58 \pm 0.36$ \\
\hline \multirow[t]{4}{*}{ HIGH HEAD } & $0.2-0.3^{\mathrm{a}}$ & $0.532 \mathrm{n} / \mathrm{a}$ & $0.368 \mathrm{n} / \mathrm{a}$ & -0.22 & 0.47 & $6.90 \mathrm{n} / \mathrm{a}$ & $11.69 \mathrm{n} / \mathrm{a}$ \\
\hline & $0.5-0.6^{\mathrm{b}}$ & $0.364 \pm 0.02$ & $0.200 \pm 0.02$ & -0.68 & $1.06 \pm 0.13$ & $6.97 \pm 0.06$ & $9.58 \pm 2.38$ \\
\hline & 2 & $0.241 \pm 0.10$ & $0.077 \pm 0.10$ & -4.43 & $1.96 \pm 0.11$ & $6.98 \pm 0.10$ & $0.23 \pm 0.08$ \\
\hline & 8 & $0.132 \pm 0.03$ & $-0.033 \pm 0.03$ & -6.55 & $3.95 \pm 0.08$ & $6.68 \pm 0.03$ & $0.12 \pm 0.03$ \\
\hline \multirow[t]{2}{*}{ WET HEAD } & $0.2-0.3$ & $-0.450 \pm 0.05$ & $-0.614 \pm 0.05$ & -2.34 & $3.89 \pm 0.32$ & $6.38 \pm 0.03$ & $22.93 \pm 5.16$ \\
\hline & $0.5-0.6$ & $0.277 \pm 0.08$ & $0.113 \pm 0.08$ & -0.77 & $5.95 \pm 0.17$ & $6.68 \pm 0.07$ & $9.89 \pm 2.79$ \\
\hline \multirow[t]{2}{*}{ NEAR TAIL } & $0.2-0.3$ & $-0.091 \pm 0.05$ & $-0.255 \pm 0.05$ & -5.23 & $4.94 \pm 0.44$ & $6.50 \pm 0.04$ & $1.00 \pm 0.42$ \\
\hline & $0.5-0.6$ & $0.468 \pm 0.06$ & $0.304 \pm 0.06$ & -3.87 & $4.65 \pm 0.35$ & $6.70 \pm 0.07$ & $0.86 \pm 0.37$ \\
\hline \multirow[t]{5}{*}{ FAR TAIL } & 0 & $-0.187 \pm 0.08$ & $-0.352 \pm 0.08$ & -4.80 & $3.64 \pm 0.53$ & $7.13 \pm 0.08$ & $0.21 \pm 0.04$ \\
\hline & $0.1-0.3$ & $-0.756 \pm 0.04$ & $-0.921 \pm 0.04$ & -7.18 & $5.10 \pm 1.41$ & $6.40 \pm 0.09$ & $0.48 \pm 0.15$ \\
\hline & $0.4-0.5$ & $-0.120 \pm 0.24$ & $-0.284 \pm 0.24$ & -5.11 & $6.59 \pm 1.30$ & $6.53 \pm 0.06$ & $0.70 \pm 0.21$ \\
\hline & 2 & $0.338 \pm 0.02$ & $0.174 \pm 0.02$ & -5.46 & $8.17 \pm 0.18$ & $6.60 \pm 0.00$ & $0.28 \pm 0.04$ \\
\hline & 8 & $0.442 \pm 0.01$ & $0.277 \pm 0.01$ & -5.76 & $8.46 \pm 0.14$ & $6.60 \pm 0.00$ & $0.22 \pm 0.01$ \\
\hline \multirow[t]{5}{*}{ MARSH } & 0 & $-0.142 \pm 0.03$ & $-0.306 \pm 0.03$ & -4.45 & $3.80 \pm 0.48$ & $7.18 \pm 0.03$ & $0.24 \pm 0.04$ \\
\hline & $0.1-0.3$ & $-0.429 \pm 0.11$ & $-0.594 \pm 0.11$ & -7.72 & $6.28 \pm 0.48$ & $6.43 \pm 0.09$ & $0.25 \pm 0.03$ \\
\hline & $0.4-0.5$ & $-0.490 \pm 0.05$ & $-0.655 \pm 0.05$ & -8.23 & $5.74 \pm 0.50$ & $6.38 \pm 0.05$ & $0.22 \pm 0.02$ \\
\hline & 2 & $0.155 \pm 0.01$ & $-0.009 \pm 0.01$ & -6.51 & $8.67 \pm 0.07$ & $6.69 \pm 0.01$ & $0.12 \pm 0.03$ \\
\hline & 8 & $0.137 \pm 0.02$ & $-0.027 \pm 0.02$ & -6.49 & $8.38 \pm 0.10$ & $6.65 \pm 0.02$ & $0.14 \pm 0.03$ \\
\hline
\end{tabular}

a $n=1$

Finally, using the porewater recharge and lateral specific discharge rates that characterized variability in hydrologic conditions (Table 1), we quantified hydrologic $\mathrm{P}$ fluxes for these periods (Table 3). P flux associated with High Head 
Table 2b. Multivariate analysis of variance using a mixed effects model structure of summary hydrogeochemical parameters by community (High Head - HH, Far Tail - FT and Marsh) and water type, with water type categorized by depth: shallow soil water (SSW - 0.3 and $0.6 \mathrm{~m}$ ) and groundwater (GW-2 and $8 \mathrm{~m})$.

\begin{tabular}{|c|c|c|c|c|c|c|c|c|c|c|c|}
\hline \multirow[b]{2}{*}{ Effect } & \multirow[b]{2}{*}{ Level } & \multicolumn{2}{|c|}{ TDP } & \multicolumn{2}{|c|}{ SI $\mathrm{I}_{\text {calcite }}$} & \multicolumn{2}{|c|}{$\mathrm{SI}_{\text {aragonite }}$} & \multicolumn{2}{|c|}{$\mathrm{Ca} / \mathrm{Cl}$} & \multicolumn{2}{|c|}{$\mathrm{pH}$} \\
\hline & & $F$ ratio & $\mathrm{MC}$ & $F$ ratio & $\mathrm{MC}$ & $F$ ratio & $\mathrm{MC}$ & $F$ ratio & MC & $F$ ratio & $\mathrm{MC}$ \\
\hline \multirow[t]{3}{*}{ Community } & $\mathrm{HH}$ & $77.1^{* * *}$ & $\mathrm{a}$ & $22.8^{* *}$ & $\mathrm{a}$ & $22.8^{* *}$ & $\mathrm{a}$ & $101^{* * *}$ & $\mathrm{~b}$ & $19.5^{* *}$ & a \\
\hline & FT & & $\mathrm{b}$ & & $\mathrm{b}$ & & $\mathrm{b}$ & & $\mathrm{a}$ & & $\mathrm{b}$ \\
\hline & Marsh & & $\mathrm{c}$ & & $\mathrm{c}$ & & $\mathrm{c}$ & & $\mathrm{a}$ & & $\mathrm{b}$ \\
\hline \multirow[t]{2}{*}{ Water type } & SSW & $209^{* * *}$ a & $25.2^{* * *}$ & $\mathrm{~b}$ & $25.2^{* * *}$ & $\mathrm{~b}$ & $24.5^{* * *}$ & $\mathrm{~b}$ & $4.1(\mathrm{NS})$ & & \\
\hline & $\mathrm{GW}$ & & $\mathrm{b}$ & & $\mathrm{a}$ & & $\mathrm{a}$ & & $\mathrm{a}$ & & \\
\hline \multirow{6}{*}{$\begin{array}{l}\text { Community } * \\
\text { water type }\end{array}$} & $\mathrm{HH}^{*} \mathrm{SSW}$ & $88.4^{* * *}$ & a & $10.1^{* *}$ & a & $10.1^{* *}$ & $\mathrm{a}$ & $0.11(\mathrm{NS})$ & & $8.4^{*}$ & a \\
\hline & $\mathrm{HH}^{*} \mathrm{GW}$ & & $\mathrm{c}$ & & $\mathrm{a}$ & & $\mathrm{a}$ & & & & $a b$ \\
\hline & $\mathrm{FT}^{*} \mathrm{SSW}$ & & $\mathrm{b}$ & & $\mathrm{b}$ & & $\mathrm{b}$ & & & & $\mathrm{cd}$ \\
\hline & $\mathrm{FT} * \mathrm{GW}$ & & $\mathrm{c}$ & & $\mathrm{a}$ & & $\mathrm{a}$ & & & & bcd \\
\hline & Marsh * SSW & & $\mathrm{bc}$ & & $\mathrm{b}$ & & $\mathrm{b}$ & & & & d \\
\hline & Marsh * GW & & $\mathrm{c}$ & & $\mathrm{a}$ & & $\mathrm{a}$ & & & & $\mathrm{bc}$ \\
\hline
\end{tabular}

$F$ ratio, $p$ value $\left(* * * p<0.0001,{ }^{* *} p<0.001,{ }^{*} p<0.01\right.$, and NS - not significant) and results of multiple comparisons (MC) tests are provided. Letters indicate significantly different main effects or interaction effects with "a" indicating the highest mean value.

porewater recharge was generally 2-3 orders of magnitude higher than lateral $\mathrm{P}$ fluxes. Due to the higher $\mathrm{P}$ concentrations at $30 \mathrm{~cm}$ depth in the Wet Head, P flux associated with porewater recharge at $30 \mathrm{~cm}$ depth was similar to fluxes in the High Head and an order of magnitude higher than at $60 \mathrm{~cm}$ depth (Table 3). We then evaluated the relationship of regional climate drivers of precipitation, evapotranspiration, and tree island water level on fluxes of water and $\mathrm{P}$ using regression analyses (Tables 1 and 3, Fig. 5). Precipitation explained 91 and $76 \%$ of the variance in rates of High Head porewater recharge and associated $\mathrm{P}$ flux at $60 \mathrm{~cm}$ depth in positive relationships $\left(r^{2}=0.91, y=2.05+0.060 x, F=\right.$ 42.57, $p=0.003$ and $r^{2}=0.76, y=21.27+0.467 x, F=$ $12.64, p=0.024$, respectively). Precipitation also explained 79 and $84 \%$ of the variance in rates of Wet Head porewater recharge and $\mathrm{P}$ flux at $30 \mathrm{~cm}$ depth in positive relationships $\left(r^{2}=0.79, y=4.36+0.014 x, F=14.93, p=0.018\right.$ and $\left.r^{2}=0.84, y=42.07+0.329 x, F=21.05, p=0.010\right)$. There was no relationship between precipitation and porewater P flux at $60 \mathrm{~cm}$ depth in the Wet Head. Neither precipitation nor Prec-ET were significantly related to tree island water level, but water level was significantly related to the lateral head gradient between High Head and Wet Head and the lateral $\mathrm{P}$ flux in polynomial and linear relationships, respectively $\left(r^{2}=0.97, y=-5.0 \times 10^{-6} x^{2}+0.0009 x+1.30\right.$, $F=37.68, p=0.007$ and $r^{2}=0.75, y=7.84+0.008 x$, $F=11.76, p=0.027)$.

\section{Discussion}

In an Everglades tree island, geochemical processes mediating phosphorus $(\mathrm{P})$ dynamics were associated with plant biological activity, topographic setting and hydraulic pat- terns at the local scale and factors of climate, geology and hydrology at the regional scale. The pattern of total dissolved phosphorus (TDP) and its transport along a forestmarsh gradient was consistent with the chemohydrodynamic nutrient (CHNT) hypothesis and further informed by the trigger-transfer, pulse-reserve (TTPR) model (Ludwig et al., 2005). Our study illustrated coincident patterns along scales of space and time, and their interactions, and highlighted the processes conducive to soil $\mathrm{P}$ maintenance in an Everglades tree island (Fig. 6). The basis for comparison with the TTPR model for semiarid systems broadens the application of our study.

Comparison with the drylands TTPR model was well founded due to the presence of a reserve patch (source) and processes related to strong seasonality as illustrated in Fig. 6: (1) spatial context - concentration of the limiting resource (P) in islands of fertility as compared with a resource-poor landscape (Schlesigner and Pilmanus, 1998); (2) temporal trigger - soil zone calcite precipitation requiring strong seasonality for evapotranspiration to promote conditions for secondary soil development and $\mathrm{CaP}$ reprecipitation (Candy et al., 2006); (3) temporal trigger and spatio-temporal transfer - rewetting of previously dry soils by rain events at the onset of the wet season and lateral flux (Campo et al., 1998; McCrackin et al., 2008); and (4) spatial context and spatiotemporal transfer - antecedent conditions of the reserve patch including landscape position, topography, and soil moisture (Austin et al., 2004) that modulated the effect of the precipitation trigger (i.e., hydrologic pulse; Jenerette and Chatterjell, 2012). Taken together, these processes promoted the potential for $\mathrm{P}$ retention through secondary mineral soil development and seasonal hydrologic transport of $\mathrm{P}$ along the forest-marsh gradient. 
Table 3. Intra-annual variability in vertical (recharge) and lateral porewater total dissolved phosphorus (TDP) fluxes. See text for details of calculations.

\begin{tabular}{|c|c|c|c|c|}
\hline \multirow[b]{3}{*}{ Season } & \multicolumn{3}{|c|}{$\begin{array}{l}\text { Porewater vertical } \\
\qquad \begin{array}{l}\text { P flux } \\
\mu g \mathrm{P} \mathrm{m}^{-2} \mathrm{~d}^{\mathrm{a}}\end{array}\end{array}$} & \multirow{3}{*}{$\begin{array}{r}\text { Porewater } \\
\text { lateral P flux } \\
\mu \mathrm{P} \mathrm{m}^{-2} \mathrm{~d}^{\mathrm{a}} \\
\begin{array}{r}\text { High Head- } \\
\text { Wet Head }\end{array} \\
0.6 \mathrm{~m}\end{array}$} \\
\hline & \multirow{2}{*}{$\begin{array}{l}\text { High } \\
\text { Head } \\
0.6 \mathrm{~m}\end{array}$} & \multicolumn{2}{|c|}{$\begin{array}{l}\text { Wet } \\
\text { Head }\end{array}$} & \\
\hline & & $0.3 \mathrm{~m}$ & $0.6 \mathrm{~m}$ & \\
\hline $\begin{array}{l}\text { Early dry } \\
\text { (Feb-Mar 2008) }\end{array}$ & 69.9 & 41.9 & 33.4 & 4.4 \\
\hline $\begin{array}{l}\text { Dry } \\
\text { (Apr and Jun 2008) }\end{array}$ & 265.5 & 168.4 & 12.2 & 5.4 \\
\hline $\begin{array}{l}\text { Early wet } \\
\text { (Jul-Aug 2008) }\end{array}$ & 202.8 & 194.9 & 10.4 & 5.0 \\
\hline $\begin{array}{l}\text { Wet } \\
\text { (Sep-Oct 2008) }\end{array}$ & $63.2^{\mathrm{b}}$ & $120.7^{b}$ & $7.4^{\mathrm{b}}$ & $8.8^{\mathrm{b}}$ \\
\hline $\begin{array}{l}\text { Late wet } \\
\text { (Nov-Dec 2008) }\end{array}$ & $45.2^{\mathrm{b}}$ & $72.1^{\mathrm{b}}$ & $4.4^{\mathrm{b}}$ & $10.0^{\mathrm{b}}$ \\
\hline $\begin{array}{l}\text { Late late wet } \\
\text { (Jan-Feb 2009) }\end{array}$ & 46.7 & 53.1 & 3.3 & 6.1 \\
\hline
\end{tabular}

$\mathrm{a}$ applying porosity of $0.75,{ }^{\mathrm{b}}$ assumes similar TDP concentrations as Jan-Feb 2009.

\subsection{Characteristics of the source patch - the point of initiation for $P$ dynamics}

Tree islands of the fixed, tear-drop shape type have soil total $\mathrm{P}$ associated with High Head plant communities that are 10-100 times higher than soils of other tree island and marsh plant communities (Ross and Sah, 2011; Wetzel et al., 2011). Our study was consistent with this general feature of High Head soils of this tree island type where high soil porewater $\mathrm{P}$ concentrations have also been reported (Saha et al., 2009). Across the Everglades, high soil P concentrations have been associated with non-carbonate mineral content of the soil (Ross and Sah, 2011). For the tree island we intensively studied, we found the non-carbonate component of the soils to be Ca-bound phosphate that comprised approximately $50 \%$ of the soil total P by mass in the High Head (Fig. 2b).

In the P-limited Everglades, the source of tree island soil $\mathrm{P}$ is attributed to a number of factors, including deposition of faunal and human remains as bioapatite (a biologically derived analog to the phosphate mineral hydroxyapatite; Pasteris et al., 2008) during tree island development (Carr 2002; Graf et al., 2008; Willard et al., 2006). After tree island establishment, sources are additionally attributed to Native American use (Bernhardt, 2012), aeolian deposition (Wetzel et al., 2005), and evapotranspiration resulting in mineral exchange and evaporative concentration of $\mathrm{P}$ and ions (Saha et al., 2009, 2010; Sullivan et al., 2012).
The enigmatic mineral soils that occur in the High Head have been identified as a pedogenic calcrete layer (Graf et al., 2008). Pedogenic or secondary carbonate precipitation can occur upon the interaction of a source of $\mathrm{Ca}$ ions and dissolved $\mathrm{CO}_{2}$ and in terrestrial systems is most frequently documented for semiarid climates (Brasier, 2011). The degassing of $\mathrm{CO}_{2}$ enables the precipitation reaction as a function of temperature shifts, evapotranspiration, the common ion effect and presence of vascular plants (Brasier, 2011). Early studies illustrated that the $\mathrm{CO}_{2}$ incorporated into secondary carbonates in some systems is root- or rhizospherederived (Cerling et al., 1989). Recent studies by Gocke and Kuzyakov (2011) and Gocke et al. (2011) showed that the presence of plant roots and increased temperature increased the rate of carbonate recrystallization. They estimated from model predictions that nearly $100 \%$ recrystallization of a $\mathrm{CaCO}_{3}$ parent material can occur in $60 \mathrm{yr}$ provided certain field-applicable conditions. They also identified the primary zone of secondary carbonate formation to be $15-50 \mathrm{~cm}$ depth (Gocke et al., 2012). Thus, mineral soil development in the High Head can occur within the timescale of Everglades water management changes. The vertical location of calcrete deposition suggests that water depths resulting in continuous inundation of the upper soil profile potentially diminish secondary mineral formation. Conversely some degree of soil aeration (i.e., topographic position) is an important factor in High Head soil development. This potential for recrystallization of $\mathrm{CaCO}_{3}$ suggests that the formation of secondary phosphates is feasible, that the mineral Ca-bound $\mathrm{P}$ fraction may result from this process and that actions taken to restore hydrology in the Everglades could result in significant mineral soil development within $60 \mathrm{yr}$.

\subsection{Interactions of hydrogeochemistry and plant biological activity}

Another unique character of the High Head mineral soils (as compared with soils of other plant communities within the tree island) was soil water concentrated in accumulated ions. $\mathrm{Cl}$ accumulation is demonstrated by numerous studies to indicate physical evaporation and transpiration by plants (Grimaldi et al., 2009; Jobbagy and Jackson, 2007). Newman et al. (2010) showed that high $\mathrm{Cl}$ concentrations were correlated with proportionally higher transpiration than evaporation. The authors also illustrated a drawdown in water table that was related to root activity in treed patches with the effect of drawing in soil water from adjacent intercanopy patches. The effect of treed patches on soil water table level has been shown experimentally for created Everglades tree islands and associated with increased $\mathrm{Cl}$ concentrations ( $\mathrm{Sul}-$ livan et al., 2011, 2012).

Consequently, by increasing ion concentrations, differential evapotranspiration in treed patches can promote mineral deposition through localized calcite precipitation around roots (Brasier, 2011). Results from our study were consistent 


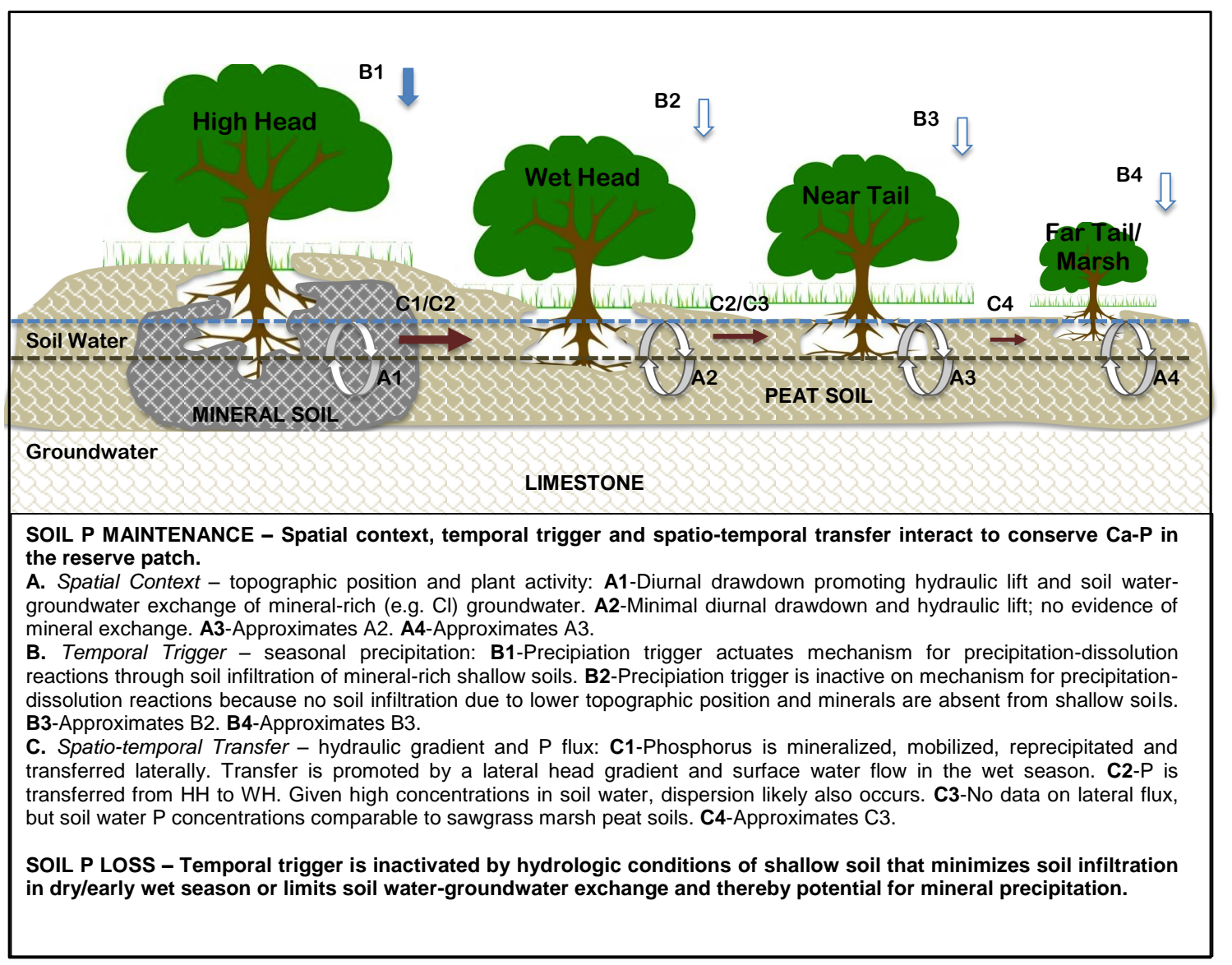

Fig. 6. Conceptual model illustrating the interactions of local climatic, biotic and hydrogeochemical processes that facilitate phosphorus dynamics along an Everglades tree island forest-marsh gradient.

with this; preferential accumulation of $\mathrm{Cl}$ coincided with conditions favoring mineral precipitation (i.e., $\mathrm{CaCO}_{3}$ supersaturation) in association with the primary rooting zone in the High Head. However, some degree of soil exposure is required to enable plants to exert this concentration effect on the soil water table and for mineral precipitation to occur. This is also consistent with climate conditions in semiarid environments. In order for calcrete formation to occur, strong seasonality that results in evapotranspiration exceeding precipitation is required (Candy et al., 2006). In the Everglades, this strong seasonality is typical, resulting in a precipitation deficit that begins at the end of the wet season, and subsequently high evapotranspiration with low regional water levels at the height of the dry season (April-May).

It is also notable that water sampled from all profiles within each community showed strong potential for dissolution of hydroxyapatite - except in the soil water of the High Head and at $0.5-0.6 \mathrm{~m}$ depth in the Wet Head. This could be explained by a positive relationship between $\mathrm{SI}_{\text {hydroxyapatite }}$ and $\mathrm{SI}_{\text {calcite }}$ among samples of the soil water profile $\left(r^{2}=\right.$ $0.58, p<0.05$ in linear regression). Along the flowpath from High Head to Wet Head, the soil water shifts to a water that is undersaturated with respect to calcite, aragonite and hydroxyapatite - likely a result of dissolution by infiltrating water that is low $\mathrm{pH}$ and rich in dissolved $\mathrm{CO}_{2}$ from rain, plant leachates or peat soil in the Wet Head (and low alkalinity; Hinsinger, 2001; Seigel et al., 2006). The dissolution of all three Ca-bearing minerals in the soil water of the Wet Head would be expected to release $\mathrm{P}$ consistent with the high concentrations of TDP and SRP observed there.

Given the important effect of redox state on $\mathrm{P}$ availability in wetland soils, there is also the potential for redox-driven spatial differences in TDP between High Head (more oxidized) and Wet Head (more reduced). We found that Febound soil TP increased from High Head to the Wet Head, suggesting an additional source of dissolved $\mathrm{P}$ with reduction of Fe(III)-oxides (Hutchison and Hesterberg, 2004; Mortimer, 1971). While this redox-driven process can affect $P$ availability as described, soil TP density in Wet Head soils were nearly 100 times lower than in High Head soils. Furthermore, despite the variation in DO between High Head and Wet Head at the same depth $(0.5-0.6 \mathrm{~m})$, TDP and SRP were similar. Moreover, given that Wet Head soils are an unlikely source of $\mathrm{P}$ due to low $\mathrm{P}$ peat and alkalinity of waters 
in shallow soil, both lateral transport to and dissolution in this profile are supported.

The soil water conditions of the Far Tail and Near Tail were similar to the $60 \mathrm{~cm}$ profile of the Marsh but with homogeneous geochemistry that did not change with depth. In contrast, water samples from the groundwater profile showed the opposite trend with values indicating potential for hydroxyapatite dissolution but also $\mathrm{CaCO}_{3}$ precipitation $\left(\mathrm{SI}_{\text {calcite }}\right.$ $>0.1$ ). An important additional difference between soil water of the High Head and all other waters was a lower ratio of $\mathrm{Ca} / \mathrm{Cl}$. Soil water of the High Head tended toward both $\mathrm{CaCO}_{3}$ and hydroxyapatite precipitation, had higher TDP and higher ionic strength (due to the highest $\mathrm{Cl}$ concentrations among other ions).

\subsection{Seasonal precipitation events and $P$ transport}

Relationships between seasonal water deficit and dry-wet cycles with $\mathrm{P}$ dynamics illustrate that rewetting of previously dried soils can increase $\mathrm{P}$ availability and, in some cases, subsequent storage (Campo et al., 1998; Carreira et al., 2006; Chacon, 2009). In the tree island we studied, we found significant relationships among precipitation events, porewater TDP concentrations, and porewater P flux. We determined that $67 \%$ of the annual vertical P flux occurred between April and August. At least $70 \%$ of the vertical porewater $P$ flux during diurnal drawdown was associated with the effect of precipitation events when regional water levels were lowest. The precipitation pulse enhanced porewater $\mathrm{P}$ flux at the transition between dry and wet seasons: (1) by increasing the daily recovery of evacuated pore space and exchange of P-enriched soil water with P-depleted surface or rain water, possibly over a diffusion gradient and (2) via recharge of the remaining exposed soil water profile, influencing release of $\mathrm{P}$ through dissolution reactions. For example, soil zone $\mathrm{CO}_{2}$ has been shown to increase with the onset of precipitation events in a semiarid system (Sponseller, 2007; Harms and Grimm, 2012). In carbonate systems, soil $\mathrm{CO}_{2}$ can also increase the potential recrystallization rate of minerals of both $\mathrm{CaCO}_{3}$ and $\mathrm{CaPO}_{4}$ with reincorporation of $\mathrm{P}$ into the soil matrix (Brasier, 2011). Long et al. (2008) found P release into porewater that was associated with $\mathrm{CO}_{2}$ release from root exudates in a seagrass meadow with carbonate sediments. In a seasonally dry tropical forest, a large proportion of the released $\mathrm{P}$ was reincorporated into the soil (Campo et al., 1998). Thus, in tree island soils, rewetting of the soil profile above the water table influenced the flux of $\mathrm{P}$ through the effects of both diurnal drawdown and precipitation events but precipitation was estimated to mobilize the largest flux of P. Moreover, P release and reprecipitation in the soil matrix within the source patch and the extent of lateral transport along the forest-marsh gradient is consistent with the TTPR model and will determine whether the tree island is a sink or source of $\mathrm{P}$

\subsection{The influence of antecedent conditions}

Our study also illustrated how antecedent conditions, whether a function of seasonal water availability or topographic setting of the plant community, not only modulated the effect of precipitation events as in semiarid lands (Sponseller, 2007; Jenerette and Chatterjell, 2012) but also soil water-groundwater interaction. Greater diurnal drawdown and higher porewater recharge rates coincided with topographic position of the High Head that had $30-40 \mathrm{~cm}$ lower water levels on average than other communities. Precipitation was an important explanatory variable describing vertical porewater hydrologic and P fluxes in both the High Head and Wet Head, but the depth of the water table below the soil surface in the High Head contributed to higher porewater flux rates at the onset of the wet season. The higher topographic setting contributed to the head gradient between the High Head and Wet Head and consequently lateral flux of $\mathrm{P}$ along the forest-marsh gradient that was influenced by the increase in the regional water table.

Soil water-groundwater exchange in the High Head was also evident; however, groundwater was not the source of $\mathrm{P}$ to High Head soil water. Interaction effects showed that $\mathrm{SI}_{\text {calcite }}$ and $\mathrm{SI}_{\text {aragonite }}$ in shallow soil water of the High Head and all deep groundwater sources tested (High Head, Far Tail and Marsh at $2 \mathrm{~m}$ and $8 \mathrm{~m}$ depth) were not significantly different, illustrating the potential for vertical exchange of soil water and groundwater. Despite this apparent connectivity between soil water and groundwater in the High Head, the concentration of TDP was highest in soil water of the High Head (at $0.6 \mathrm{~m}$ depth) and Wet Head (at $0.3 \mathrm{~m}$ depth) as compared with all other water sources. In contrast, groundwater TDP concentrations were negligible. Thus, high soil $\mathrm{P}$ concentrations and the lateral flux patterns suggested the High Head was the source of P to shallow Wet Head soils at $0.3 \mathrm{~m}$ depth. Although we were not able to sample groundwater of the Wet $\mathrm{Head}$, soil water saturation indices and $\mathrm{Ca} / \mathrm{Cl}$ suggested a lack of soil water-groundwater exchange there, assuming that groundwater concentrations did not differ significantly from other groundwater samples (a reasonable assumption given the low variability of groundwater sampled). Low $\mathrm{P}$ concentrations in Wet Head soils and low TDP in groundwater further supported that the source of $\mathrm{P}$ to shallow Wet Head soils was associated with proximity to the High Head and not a localized or groundwater source.

\section{Conclusions}

Application of the trigger-transfer, pulse-reserve (TTPR) model draws out an enhanced understanding of internal $P$ dynamics and the mechanisms by which precipitation events and antecedent conditions of soil saturation can modulate the mobility and fate of P. The balance between internal recycling and loss from the system can be critical, not only 
for maintaining landscape habitat structure but also preventing local nutrient enrichment. With extensive water management, seasonal hydrologic dynamics can be asynchronous with both biological and geochemical dynamics, tipping the balance between a sink and source of a limiting nutrient. Specifically, over-flooded or over-dry conditions may not only reduce potential for soil zone ion accumulation and mineral stability but also recycling of nutrients. Yet, model predictions suggest the timescale for mineral soil development is on the order of $50 \mathrm{yr}$ as compared with peat soils which develop over millennia. Thus, tree island soils could be restored in areas where they have been degraded given the restoration of biotic and hydrogeochemical conditions described here. Moreover, this study illustrates: (1) the utility of applying the TTPR model in other strongly seasonal environments and (2) how integration of biological and hydrogeochemical processes can be considered as a tool to refine management actions and address issues of large-scale environmental change.

\section{Supplementary material related to this article is available online at http://www.biogeosciences.net/11/899/ 2014/bg-11-899-2014-supplement.pdf.}

Acknowledgements. This research would not have been possible without the hard work of O. Sanchez, A. Hines, R. Travieso, and G. Losada. Earlier drafts of this manuscript were significantly improved by editorial comments provided by S. Davis, T. Dreschel, and P. Wetzel. We gratefully acknowledge funding by the South Florida Water Management District. This is Southeast Environmental Research Center contribution number 623. A portion of Price's time was supported by NSF Grant No. DBI-0620409 and the NASA WaterSCAPES project.

Edited by: T. Treude

\section{References}

Austin, A. T., Yahdjian, L., Stark, J. M., Belnap, J., Porportato, A., Norton, U., Ravetta, D. A., and Schaeffer, A. M.: Water pulses and biogeochemical cycles in arid and semiarid ecosystems, Oecologia, 141, 221-235, 2004.

Bauer-Gottwein, P., Langer, T., Prommer, H., Wolski, P., and Kinzelbach, W.: Okavango Delta islands: Interaction between density-driven flow and geochemical reactions under evapoconcentration, J. Hydrol., 335, 389-405, 2007.

Bernhardt, C.: Native Americans, regional drought and tree island evolution in the Florida Everglades, Holocene, 21, 967-978, 2011.

Bevier, C. and Krupa, S.: Groundwater-surface water interaction in tree islands: Water Conservation Area 3. Part 1: Phase 1 Well Installation, Technical Publication WS-4, South Florida Water Management District, West Palm Beach, FL, USA, 20 pp., 2001.
Brasier, A. T.: Searching for travertines, calcrete and speleothems in deep time: processes, appearances, predictions and the impact plants, Earth-Sci. Rev., 104, 213-239, 2011.

Campo, J., Jaramillo, V. J., and Maass, J. M.: Pulses of soil phosphorus availability in a Mexican tropical dry forest: effects of seasonality and level of wetting, Oecologia, 115, 167-172, 1998.

Candy, I., Rose, J., and Lee, J.: A seasonally "dry" interglacial climate in eastern England during the early Middle Pleistocene: palaeopedological and stable isotopic evidence from Pakefield, UK, Boreas, 35, 255-265, 2006.

Carr, R. S.: The archaeology of Everglades tree islands, In Tree Islands of the Everglades, Chapter 6, edited by: Sklar, F. H. and van der Valk, A., Tree Islands of the Everglades, Kluwer Academic Publishers, Boston, MA, USA, 2002.

Carreira, J. A., Viñegla, B., and Lajtha, K.: Secondary $\mathrm{CaCO}_{3}$ and precipitation of $\mathrm{P}-\mathrm{Ca}$ compounds control the retention of soil $\mathrm{P}$ in arid ecosystems, J. Arid. Environ., 64, 460-473, 2006.

Cerling, T., Quade, J., Wang, Y., and Bowman, J. R.: Carbon isotopes in soils and paleosols as palaeoecologic indicators, Nature, 341, 138-139, 1989.

Chacon, N., Dezzeo, N., Rangel, M., and Flores, S.: Seasonal changes in soil phosphorus dynamics and root mass along a flooded tropical forest gradient in the lower Orinoco river, Venezuela, Biogeochemistry, 87, 157-168, 2008.

Davis, S. M. and Ogden, J. C.: Everglades, The Ecosystem and Its Restoration. Florida: St. Lucie Press, 1994.

Espinar, J. L., Ross, M. S., and Sah, J. P.: Pattern of nutrient availability and plant community assemblage in Everglades Tree Islands, Florida, USA, Hydrobiologia, 667, 89-99, 2011.

Frankovich, T. A. and Jones, R. D.: A rapid, precise, and sensitive method for the determination of total nitrogen in natural waters, Mar. Chem., 60, 227-234, 1998.

Gawlik, D., and Rocque, D.: Avian Communities in Bayheads, Willowheads, and Sawgrass Marshes of the Central Everglades, Wilson Bulletin, 110, 45-55, 1998.

Gerla, P. J.: The relationship of water-table changes to the capillary fringe, evapotranspiration, and precipitation in intermittent wetlands, Wetlands, 12, 91-98, 1992.

Givnish, T. J., Volin, J. C., Owen, V. D., Volin, V. C., Muss, J. D. and Glaser, P. H.: Vegetation differentiation in the patterned landscape of the central Everglades: importance of local landscape drivers, Global Ecol. Biogeogr., 17, 384-402, 2008.

Gocke, M. and Kuzyakov, Y.: Effect of temperature and rhizophere processes on pedogenic carbonate recrystallization: relevance for paleoenvironmental applications, Geoderma, 166, 57-65, 2011.

Gocke, M., Pustovoytov, K., and Kuzyakov, Y.: Carbonate recrystallization in root-free soils and rhizophere of Triticum aestivum and Lolium perenne estimated by ${ }^{14} \mathrm{C}$ labeling. Biogeochemistry, 103, 209-222, 2011.

Gocke, M., Pustovoytov, K., and Kuzyakov, Y.: Pedogenic carbonate formation: recrystallization versus migration-process rates and periods assessed by ${ }^{14} \mathrm{C}$ labeling, Global Biogeochem. Cy., 26, GB1018, doi:10.1029/2010GB003871, 2012.

Graf, M.-T., Schwardon, M., Stone, P. A., Ross, M., and Chmura, G. L.: An enigmatic carbonate layer in Everglades tree island peats, EOS Transactions AGU, 89, 117-118, 2008.

Grimaldi, C., Thomas, Z., Fossey, M., Fauvel, Y., and Merot, P. High chloride concentrations in the soil and groundwater under an oak hedge in the West of France: an indicator of evapotranspi- 
ration and water movement, Hydrol. Process., 23, 1865-1873, 2009.

Hanan, E. J. and Ross, M. S.: Across-scale patterning of plantsoil-water interactions surrounding tree islands in Southern Everglades landscapes, Landscape Ecol., 25, 463-476, 2010.

Hanan, E. J., Ross, M. S., Ruiz, P. L., and Sah, J. P.: Multiscaled grassland-woody plant dynamics in the heterogeneous marl prairies of the southern Everglades, Ecosystems, 13, 12561274. 2010

Harms, T. K. and Grimm, N. B.: Response of trace gases to hydrologic pulses in desert floodplains, J. Geophys. Res., 117, GO1035, doi:10.1029/2011JG001775, 2012.

Hieltjes, A. H. M. and Lijklema, L.: Fractionation of inorganic phosphates in calcareous sediments, J. Environ. Qual., 9, 405407, 1980

Hinsinger, P.: Bioavailability of soil inorganic P in the rhizosphere as affected by root-induced chemical changes: a review, Plant Soil, 237, 173-195, 2001.

Hutchison, K. J. and Hesterberg, D.: Dissolution of phosphate in a phosphorus-enriched ultisol as affected by microbial reduction, J. Environ. Qual., 33, 1793-1802, 2004.

Jenerette, G. D. and Chatterjee, A.: Soil metabolic pulses: water, substrate and biological regulation, Ecology, 93, 959-966, 2012.

Jobbagy, E. G. and Jackson, R. B.: Groundwater and soil chemical changes under phreatophytic tree plantations, J. Geophys. Res., 112, G02013, doi:10.1029/2006JG000246, 2007.

Long, M. H., McGlathery, K. J., Zieman, J. C., and Berg, P.: The role of organic acid exudates in liberating phosphorus from seagrass-vegetated carbonate sediments, Limnol. Oceanogr., 53, 2616-2626, 2008.

Ludwig, J. A., Wilcox, B. P., Breshears, D. D., Tongway, D. J., and Imeson, A. C.: Vegetation patches and runoff-erosion as interacting ecohydrological processes in semiarid landscapes, Ecology, 86, 288-297, 2005.

McClain, M. E., Boyer, E. W., Dent, C. L., Gergel, S. E., Grimm, N. B., Groffman, P. M., Hart, S. C., Harvey, J. W., Johnston, C. A., Mayorga, E., McDowell, W. H., and Pinay, G.: Biogeochemical hot spots and hot moments at the interface of terrestrial and aquatic ecosystems, Ecosystems, 6, 301-312, 2003.

McCormick, P. V., Newman, S., and Vilchek, L.: Landscape responses to wetland eutrophication: loss of slough habitat in the Florida Everglades, USA, Hydrobiologia, 621, 105-114, 2009.

McCrackin, M. L., Harms, T. K., Grimm, N. B., Hall, S. J., and Kaye, J. P.: Responses of soil microorganisms to resource availability in urban, desert soils, Biogeochemistry, 87, 143-155, 2008.

McNeill, D. F. and Cunningham, K. J.: Hydrostratigraphy of tree island cores from Water Conservation Area 3, US Geological Survey Open-file Report 03-68, Miami, FL, USA, 130 pp., 2003.

Mortimer, C. H.: Chemical exchanges between sediments and water in the Great Lakes-speculation on probably regulatory mechanisms, Limnol. Ocean. 16, 387-404, 1971.

Newman, B. D., Breshears, D. D., and Gard, M. O.: Evapotranspiration partitioning in a semiarid woodland: ecohydrologic heterogeneity and connectivity of vegetation patches, Vadose Zone J., 9, 561-572, 2010.

Noe, G. B., Childers, D. L., and Jones, R. D.: Phosphorus biogeochemistry and the impact of phosphorus enrichment: Why is the Everglades so unique?, Ecosystems, 4, 603-624, 2001.
Parkhurst, D. L. and Appelo, C. A. J.: User's guide to PHREEQC (v2)-A computer program for speciation, batch-reaction, onedimensional transport, and inverse geochemical calculations: US Geological Survey Water-Resources Report, 312 pp., 1999.

Pasteris, J. D., Wopenka, B., and Valsami-Jones, E.: Bone and tooth mineralization: why apatite?, Elements, 4, 97-104, 2008.

Patterson, K. and Finck, R.: Tree Islands of the WCA3 aerial photointerpretation and trend Analysis: project summary report, St. Petersburg, FL: Geonex Corporation, Report to the South Florida Water Management District, 1999.

Reddy, K. R., Wang, Y., DeBusk, W. F., Fisher, M. M., and Newman, S.: Forms of soil phosphorus in selected hydrologic units of the Florida Everglades, Soil Sci. Soc. Am. J., 62, 1134-1147, 1998

Ross, M. S., Mitchell-Bruker, S., Sah, J. P., Stothoff, S., Ruiz, P. L., Reed, D. L., Jayachandran, K., and Coultas, C. L.: Interaction of hydrology and nutrient limitation in the Ridge and Slough landscape of the southern Everglades, Hydrobiologia, 569, 37-59, 2006.

Ross, M. S. and Sah, J. P.: Forest resource islands in a sub-tropical marsh: soil-site relationships in Everglades Hardwood Hammocks, Ecosystems, 14, 632-645, 2011.

Saha, A. K., Sternberg, L. L. O., and Miralles-Wilhelm, F.: Linking water sources with foliar nutrient status in upland plant communities in the Everglades National Park, USA, Ecohydrology, 2, 42-54, 2009

Saha, A. K., Sternberg, L., Ross, M. S., and Miralles-Wilhelm, F.: Water source utilization and foliar nutrient status differs between upland and flooded plant communities in wetland tree islands, Wetlands Ecol. Manag., 18, 343-355, 2010.

Schlesinger, W. H. and Pilmanis, A.: Plant-soil interactions in deserts, Biogeochemistry, 42, 169-187, 1998.

Schwartz, F. W. and Zhang, H.: Fundamentals of Groundwater, John Wiley and Sons, Inc., New York, New York, USA, 2003.

Science Coordination Team: The role of flow in the Everglades Ridge and Slough landscape, South Florida Ecosystem Restoration Working Group, http://sofia.usgs.gov/publications/papers/ sct_flows/i, 2003.

Siegel, D. I., Glaser, P. H., So, J., and Janecky, D. R.: The dynamic balance between organic acids and circumneutral groundwater in a large boreal peat basin, J. Hydrol., 320, 421-431, 2006.

Sklar, F. H. and van der Valk, A.: Tree islands of the Everglades: an overview, in: Tree Islands of the Everglades, edited by: Sklar, F. H. and van der Valk, A., Tree Islands of the Everglades, Kluwer Academic Publishers, Boston, MA, USA, 1-18, 2002.

Sponseller, R. A.: Precipitation pulses and soil $\mathrm{CO}_{2}$ flux in a Sonoran Desert ecosystem, Glob. Change Biol., 13, 426,-436, 2007.

Solorzano, L. and Sharp, J.: Determination of total dissolved P and particulate $\mathrm{P}$ in natural waters, Limnol. Oceanogr., 25, 754-758, 1980.

South Florida Water Management District: Satellite-based solar radiation, net radiation, and potential and reference evapotranspiration estimation over Florida, technical report prepared by Jennifer Jacobs, John Mecikalski and Simon Paech, South Florida water management district, West Palm Beach, Florida, 2008.

Sullivan, P. L., Price, R. M., Miralles-Wilhelm, F., Ross, M. S., Scinto, L. J., Dreschel, T. W., Sklar, F. H., and Cline, E.: The role of recharge and evapotranspiration as hydraulic drivers of ion concentrations in shallow groundwater on Everglades tree is- 
lands, Florida (USA). Hydrol. Process., doi:10.1002/hyp.9575, 2012.

Sullivan, P. L., Price, R. M., Ross, M. S., Scinto, L. J., Stoffella, S., Cline, E., Dreschel, T. W., and Sklar, F. H.: Hydrologic processes on tree islands in the Everglades (Florida, USA): tracking the effect of tree establishment and growth, Hydrogeology J., 19, 367-378, 2011.

Troxler, T. G. and Childers, D. L.: Litter decomposition promotes differential feedbacks in an oligotrophic southern Everglades wetland, Plant Ecol., 200, 69-82, 2009.

Troxler, T. G., Childers, D. L., and Rondeau, D. N.: Ecosystem structure and hydrologic features of tree islands in the southern Everglades. Forest Ecol. Manag., 214, 11-27, 2005.

Wang, X., Sternberg, L. O., Ross, M. S., and Engel, V. C.: Linking water use and nutrient accumulation in tree island upland hammock plant communities in the Everglades National Park, USA, Biogeochemistry, 104, 133-146, 2011.
Wetzel, P. R., van der Valk, A. G., Newman, S., Gawlik, D. E., Troxler Gann, T., Coronado-Molina, C. A., Childers, D. L., and Sklar, F. H.: Maintaining tree islands in the Florida Everglades: Nutrient Redistribution is the key, Frontiers Ecol. Environ., 3, 370376, 2005.

Wetzel, P. R., Sklar, F. H., Coronado, C. A., Troxler, T. G., Krupa, S. L., Sullivan, P. L., Ewe, S., Price, R. M., Newman, S. M., and Orem, W. H.: Biogeochemical processes on tree islands in the Greater Everglades: Initiating a new paradigm, Critical Reviews, Environ. Sci. Technol., 41, 670-701, 2011.

Willard, D. A., Bernhardt, C. E., Holmes, C. W., Landacre, B., and Marot, M.: Response of Everglades tree islands to environmental change, Ecol. Monogr., 76, 565-583, 2006. 